\title{
The effects of preeclampsia on signaling to hematopoietic progenitor cells
}

\author{
Donna A. Santillan, PhD, ${ }^{1}$ Wendy Hamilton, ${ }^{1}$ Ashley Christensen, ${ }^{3}$ Katelyn Talcott, ${ }^{3}$ \\ Lindsay Gravatt, ${ }^{1}$ Mark K. Santillan, MD, ${ }^{2}$ Stephen K. Hunter, MD PhD ${ }^{2}$
}

Keywords: pre-eclampsia, hematopoiesis, placenta, pregnancy, signal transduction

\begin{abstract}
Background: The role of the microenvironment is important in cell differentiation. The effect of placental disease on the growth and differentiation and hematopoietic stem cells has not been well-studied.
\end{abstract}

Methods: Enzyme linked immunoassay was used to measure erythropoietin and osteopontin in plasma from umbilical cord blood of children born to normotensive and preeclamptic women. Additionally, CD34+ cells were isolated from umbilical cord blood and grown in complete methylcellulose media. Colony types were identified and enumerated.

Results: Differences in the concentration of erythropoietin in the cord blood between the controls and the preeclamptics approached significance $(P=0.067)$ using a Mann-Whitney $U$ test. In the plasma of cord blood from children born to normotensive women, the median erythropoietin was $0.186 \mathrm{mIU} / \mathrm{mL}$ compared to $1.986 \mathrm{mIU} / \mathrm{mL}$ in children of preeclamptic women. We did not find any significant differences in the number and types of colonies; however, there was a trend toward increased $B F U-E$ in the preeclamptic samples. Furthermore, this trend for increased BFU-E colonies was also seen from CD34+ cells isolated from umbilical cord blood of severe preeclamptics compared to mild.

Conclusion: Our preliminary studies suggest that abnormalities in the placenta, such as those found when the mother experiences preeclampsia, may affect the ability of hematopoietic stem cells to grow and differentiate.

${ }^{1}$ Division of Reproductive Science Research, and ${ }^{2}$ Division of Maternal Fetal Medicine, The Department of Obstetrics and Gynecology, ${ }^{3}$ Roy $\mathrm{J}$. and Lucille A. Carver College of Medicine, The University of lowa, lowa City, lowa, USA.

\section{Background}

The regulation of the growth and differentiation of hematopoietic stem cells during development is quite complex. The role of the placenta in hematopoiesis is not yet well understood. Although the placenta has been shown to be a site of definitive hematopoiesis, it is unclear what impact placental disease has on hematopoietic stem cells and if there are any short or long-term ramifications to the child. To begin to address this question, we have measured cytokines from the umbilical

Please cite this paper as: Santillan DA, Hamilton W, Christensen A, Talcott K, Gravatt L, Santillan MK, Hunter SK. The effects of preeclampsia on signaling to hematopoietic progenitor cells. Proc Obstet Gynecol. 2013;3(1): Article 3 [ 11 p.]. Available from: http://ir.uiowa.edu/pog/. Free full text article.

Corresponding author: Donna Santillan, PhD, Division of Reproductive Science Research, Department of Obstetrics and Gynecology, University of lowa Hospitals and Clinics, 464 MRF, 200 Hawkins Drive, lowa City, IA 52242, Phone: (319) 3848667, Email: donna-santillan@uiowa.edu

This is an Open Access article distributed under the terms of the Creative Commons Attribution 3.0 Unported License (http://creativecommons.org/licenses/by/3.0), which permits unrestricted use, distribution, and reproduction in any medium, provided the original work is properly cited. 
cord blood of pregnancies with a normal placenta in comparison to an abnormal placenta. As placental insufficiencies are well described in preeclampsia, we have used this disease as our model of an abnormal placenta in our study of cytokines and cell growth.

Cytokines, growth factors, and chemokines are all well-known regulators of hematopoiesis. However, in vitro hematopoietic stem cell differentiation and expansion experiments demonstrate that there are other, less-well understood factors that also exert control of cell growth and differentiation. The in vivo cellular microenvironment may provide a critical influence over the cells. This microenvironment can be altered in the face of pregnancy-related diseases, such as preeclampsia. Preeclampsia is a disease of pregnancy in which parturients develop hypertension, proteinuria, and potential seizures, liver and kidney failure.

In preeclampsia, there are significant abnormalities in the placenta such as abnormal cytotrophoblast differentiation, shallow trophoblast invasion, and decreased blood flow to and from the placenta. Multiple studies of preeclampsia have found increased apoptosis in cytotrophoblasts ${ }^{1,2}$ Kadyrov confirmed an increased rate of apoptosis in trophoblast cells of spiral artery walls. ${ }^{2}$ Since spiral arteries are of maternal origin, it is likely that a maternal signal is promoting the apoptosis. The apoptotic signal may come from maternal macrophages near the spiral arteries. Large numbers of macrophages were seen in vessel cross-sections from preeclamptic women; however, macrophages were rare in sections from normal pregnancies. ${ }^{3}$ Furthermore, necrosis may occur as a result of aberrant trophoblast cell differentiation. Such necrosis of trophoblasts results in the release of cell fragments into the maternal bloodstream. These fragments are readily detected in preeclamptic maternal peripheral blood and may trigger an inflammatory response. ${ }^{4,5,6}$

Several studies point to differences in hematopoietic cell populations observed in children born to preeclamptic and normotensive mothers. Using flow cytometry, Surbek et al. demonstrated that the fetal cord blood of preeclamptic women contained fewer CD34+ positive cells $(p=0.023)$ compared to the control group. ${ }^{7}$ In addition, they found that samples from preeclamptic patients produced fewer colony forming units in erythropoietin and mixed growth factorstimulated in vitro differentiation assays. A study by Stallmach et al. found less erythroid precursors and early granulopoietic cells in fetal livers of preeclamptic affected pregnancies. $^{8}$ There is not a clear understanding of whether there are altered signaling mechanisms affecting fetal hematopoiesis in preeclampsia. Several possibilities exist including differences in cytokines and growth factors that can affect the growth and differentiation potential of cells. A recent study found significantly higher levels of leukemia inhibitory factor in placentas of preeclamptic women compared to wellmatched normotensive controls. ${ }^{9}$ Additionally, differences in osteopontin localization have been demonstrated in preeclamptic placentas. ${ }^{10}$ As osteopontin has biological functions in 
cell survival, angiogenesis, and immune function, aberrant localization may have secondary effects on cells in their microenvironment.

Another potential mechanism affecting fetal hematopoiesis, demonstrated in mice, involves the placenta as a hematopoietic organ. ${ }^{11,12,13}$ Because there is incomplete placentation in preeclampsia, this may contribute to the observed differences by leading to a reduced number of hematopoietic progenitors. A reduction in the number of hematopoietic progenitors may be responsible for the decrease in $\mathrm{CD} 3+$, CD4+, and CD8+CD28+ lymphocytes that has been observed in neonates born to mothers with severe preeclampsia. ${ }^{14}$

In this preliminary investigation, our objective was to determine if any functional differences exist in signaling by analyzing the in vitro differentiation potential of hematopoietic progenitors isolated from umbilical cord blood from babies born to women with preeclampsia compared to those born to normotensive women. In addition, we sought to identify differences in cytokines in the cord blood samples.

\section{Methods}

\section{Study subjects and sample collection}

Patient specimens were obtained through user agreements with the Institutional Review Board - approved Hematopoietic Stem Cell Bank and the Maternal Fetal Tissue Bank at the University of lowa. Umbilical cord blood samples were collected from 15 women with mild and severe preeclampsia that delivered at term (>37 weeks). The diagnosis of mild preeclampsia is made when a pregnant woman has a persistent blood pressure of $140 \mathrm{~mm} \mathrm{Hg}$ systolic or higher or $90 \mathrm{~mm} \mathrm{Hg}$ diastolic or higher that occurs after 20 weeks of gestation on 2 occasions 6 hours apart in a woman with previously normal blood pressures and proteinuria, defined as urinary excretion of $0.3 \mathrm{~g}$ protein or higher in a 24-hour urine specimen. Severe preeclampsia is defined by a systolic blood pressure $>160 \mathrm{~mm} \mathrm{Hg}$ or a diastolic blood pressure $>110 \mathrm{~mm} \mathrm{Hg}$ on at least 2 occasions $>6$ hours apart and 3-4+ proteinuria, or HELLP syndrome (severe preeclampsia with hemolysis, elevated liver enzymes, and low platelet count). Samples from a control group of 18 women with normal pregnancies were also obtained. Exclusion criteria included maternal chronic hypertension, known preexisting microvascular disease, and diabetes mellitus. Exclusion criteria of the Hematopoietic Stem Cell Bank and the Maternal Fetal Tissue Bank are maternal age less than 18 years old, $\mathrm{HIV}+$, Hepatitis $\mathrm{C}+$, inability to provide informed consent, and non-English speaking.

\section{Plasma Isolation}

Cord blood was collected as described above. Plasma was isolated using a Plasma Separator Tube (Becton Dickinson) per the manufacturer's recommendations. Plasma was immediately aliquoted, snap frozen, and stored at $-80^{\circ} \mathrm{C}$ until analysis.

\section{Cytokine Analysis}

Erythropoietin (EPO) and osteopontin (OPN) in the plasma of umbilical cord blood were analyzed using a 
commercially available ELISA assays (Platinum assays from eBioscience). All samples were analyzed in duplicate and the average of the samples was used to calculate the EPO and OPN concentrations. Manufacturer's protocols were followed for these assays.

\section{Cell Isolation and culture}

Cord blood was collected at delivery into Citrate Phosphate Dextrose Solution (Fenwal Technologies). CD34+ cells were isolated by immunomagnetic selection (StemSep, Stem Cell Technologies) from freshly collected umbilical cord blood from a subset of patients $(8 \quad$ Preeclamptics, 5 normotensive women). 500 cells from each sample were plated in duplicate in complete methylcellulose media (Methocult, Stem Cell Technologies) and incubated for 16 days at $37^{\circ} \mathrm{C}$ in $5 \%$ $\mathrm{CO}_{2}$. Colonies were identified and enumerated by visual inspection. Colony types that are expected to arise in this assay include colony-forming uniterythroid (CFU-E), burst forming uniterythroid (BFU-E), colony forming unitgranulocyte, macrophage (CFU-GM), and colony forming unit-granulocyte, erythroid, macrophage, megakaryocyte (CFU-GEMM).

\section{Statistical Analysis}

All statistical analyses were performed with SigmaStat 3.0 software (Systat Software, Inc, California). Descriptive statistics were used to characterize the data. In addition, the Fisher exact test was utilized for dichotomous variables. For continuous variables, the 2-tailed $t$ test or if criteria for normality were not met, the non-parametric Mann-Whitney $\mathrm{U}$ test was utilized. All variables were tested at significance level of 0.05 .

\section{Table 1. Maternal Demographics}

\begin{tabular}{|c|c|c|c|}
\hline Characteristic & $\begin{array}{l}\text { Control } \\
\text { (mean or } \\
\text { median) } \\
\mathrm{N}=18\end{array}$ & $\begin{array}{l}\text { Preeclamptic } \\
\text { (mean or } \\
\text { median) } \\
\mathrm{N}=15\end{array}$ & $\begin{array}{l}P \\
\text { value }\end{array}$ \\
\hline Age & 29.9 & 28.6 & $0.26^{\mathrm{a}}$ \\
\hline BMI & 29.1 & 33.7 & $0.10^{\mathrm{a}}$ \\
\hline Gravida & 2 & 2 & $0.97^{\mathrm{b}}$ \\
\hline$\%$ Caucasian & $88.9 \%$ & $93.8 \%$ & $1.0^{\mathrm{c}}$ \\
\hline
\end{tabular}

\section{Results}

We began our studies by examining differences in cytokine signaling between the preeclamptic and normotensive cord blood ( $\mathrm{N}=15$ and $\mathrm{N}=18, \quad$ respectively). Table 1 demonstrates that there were no significant differences in the age, body mass index, gravida, or percentage of Caucasians between these two groups of patients. In analyzing characteristics of their pregnancies, no differences were found in the percentage of multiples, GBS positive, diabetics, the gestational age at delivery, the rate of cesarean section, or birthweight. From these very similar groups, differences in the concentration of erythropoietin in the cord blood between the controls and the preeclamptics approached significance $(P=0.067)$ in a Mann-Whitney U. In the plasma of cord blood from children born to normotensive women, the median EPO was $0.186 \mathrm{mIU} / \mathrm{mL}$ compared to $1.986 \mathrm{mlU} / \mathrm{mL}$ in children of preeclamptic women (Figure 1). 


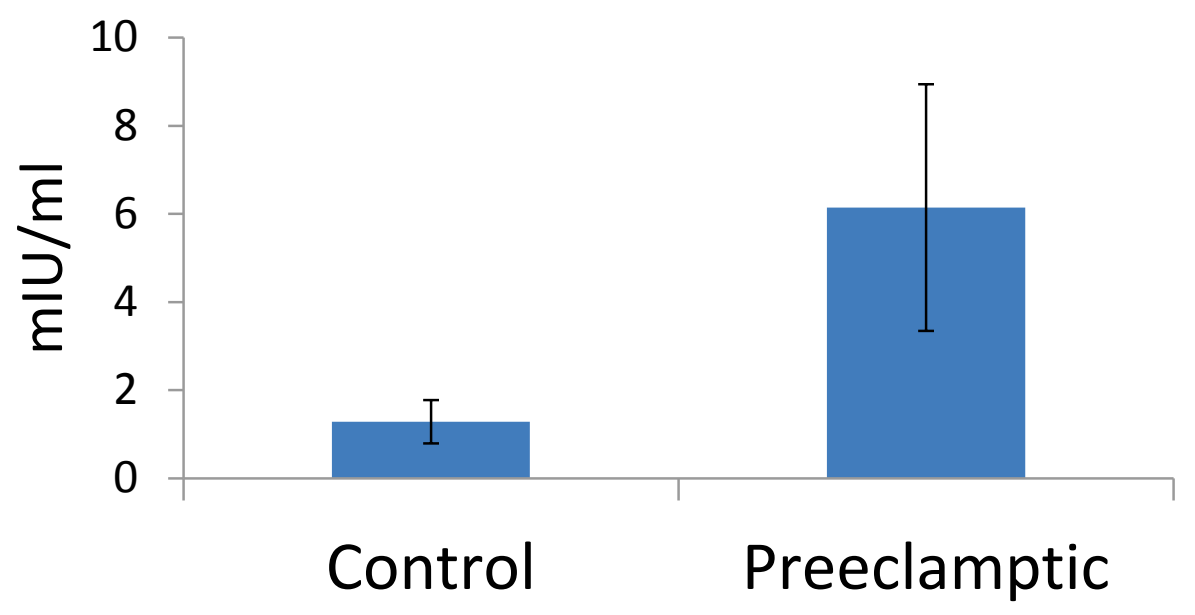

Figure 1. Erythropoietin concentration in umbilical cord blood plasma.

One marker of fetal well-being at birth is the Apgar score. Because there was a significant difference in the 1 min Apgar between groups (Table 2), we were also interested in whether there was in a difference in osteopontin concentrations in the cord blood samples between groups. Maternal plasma osteopontin has shown to be altered in women with preeclampsia who have extensive endothelial damage. ${ }^{15}$ We wanted to determine whether these differences are also found in the plasma of umbilical cord blood. Interestingly, we found a statistically significant increase in the concentration of osteopontin in the plasma of umbilical cord blood of children born to preeclamptic women compared to those born to normotensive women $\quad(44.65 \pm 2.5 \mathrm{ng} / \mathrm{ml} \quad$ versus $35.96 \pm 2.59 \mathrm{ng} / \mathrm{ml} \quad P=0.022$ ) (Figure 2). As osteopontin is also an inhibitor of hematopoietic stem cells, ${ }^{16}$ we were also interested in whether differences in colony sizes could be attributed to differences in osteopontin.

Table 2. Pregnancy Characteristics

\begin{tabular}{|l|l|l|l|}
\hline Characteristic & $\begin{array}{l}\text { Control } \\
(\% \text { or } \\
\text { mean) }\end{array}$ & $\begin{array}{l}\text { Preeclamptic } \\
(\% \text { or mean })\end{array}$ & $P$ value \\
\hline Multiples & 11.1 & 18.8 & $0.26^{\mathrm{a}}$ \\
\hline GBS positive & 41.2 & 14.3 & $0.13^{\mathrm{a}}$ \\
\hline Diabetes & 5.9 & 6.7 & $1.0^{\mathrm{a}}$ \\
\hline $\begin{array}{l}\text { Gestational } \\
\text { Age } \\
\text { Delivery }\end{array}$ & $\begin{array}{l}37 \quad 2 / 7 \\
\text { weeks }\end{array}$ & $366 / 7$ weeks & $0.54^{\mathrm{b}}$ \\
\hline C-Section & $44.4 \%$ & $53.3 \%$ & $0.874^{\mathrm{a}}$ \\
\hline $\begin{array}{l}\text { Birthweight } \\
\text { (grams) }\end{array}$ & 2921.2 & 2913.7 & $0.98^{\mathrm{b}}$ \\
\hline $\begin{array}{l}\text { 1 min } \\
\text { APGAR }\end{array}$ & 9 & 8 & $0.002^{\mathrm{c}}$ \\
\hline
\end{tabular}

a-tailed $t$ test

${ }^{\mathrm{b}}$ Mann Whitney U

${ }^{c}$ Fisher Exact Test

As other groups have reported a difference in erythropoietin and we saw a trend toward an increase in EPO in preeclamptics, we sought to determine whether in a subset of preeclamptic and normotensive patients if there was a difference in the differentiation potential of the umbilical cord stem cells when grown in methylcellulose in complete medium with identical cytokine concentrations. We did not find any significant differences in the number and types of colonies; however, there was a 
trend toward increased BFU-E in the preeclamptic samples (Figure 3). Furthermore, this trend for increased BFU-E colonies was also seen from CD34+ cells isolated from umbilical cord blood of severe preeclamptics compared to mild (Figure 4). More subjectively, colonies of all types were consistently found to be smaller in size in the colony assay of the preeclamptic samples

(Figure

$5)$.

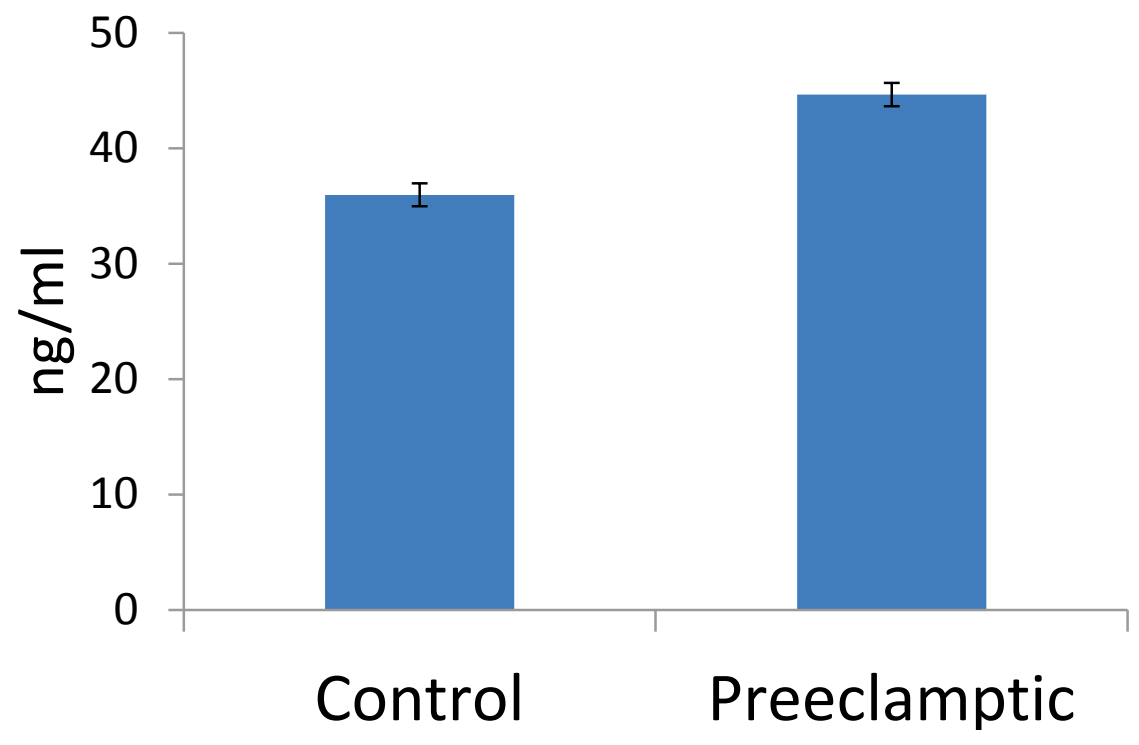

Figure 2. Osteopontin concentration in umbilical cord blood plasma. *2-tailed $t$ test $P=0.02$ vs. control.

As an equal number of cells were plated per sample, differences in colony count were not due to initial cell number. However, as other groups have found a difference in the number of hematopoietic progenitors and cord volume collected between samples from preeclamptic and normotensive mothers, we also addressed this question. No significant differences were found in the number of CD34+ cells collected or in the volume of cord blood collected. As shown in Table 3, the average total number of CD34+ cells was $4.7 \times 10^{5}$ from normotensive pregnancies compared to $5.5 \times 10^{5}$ from preeclamptic pregnancies $(P=0.80)$. The average volume of cord blood collected was $99.6 \mathrm{ml}$ in normotensive pregnancies and $75.8 \mathrm{ml}$ in preeclamptic pregnancies $(P=0.15)$. 


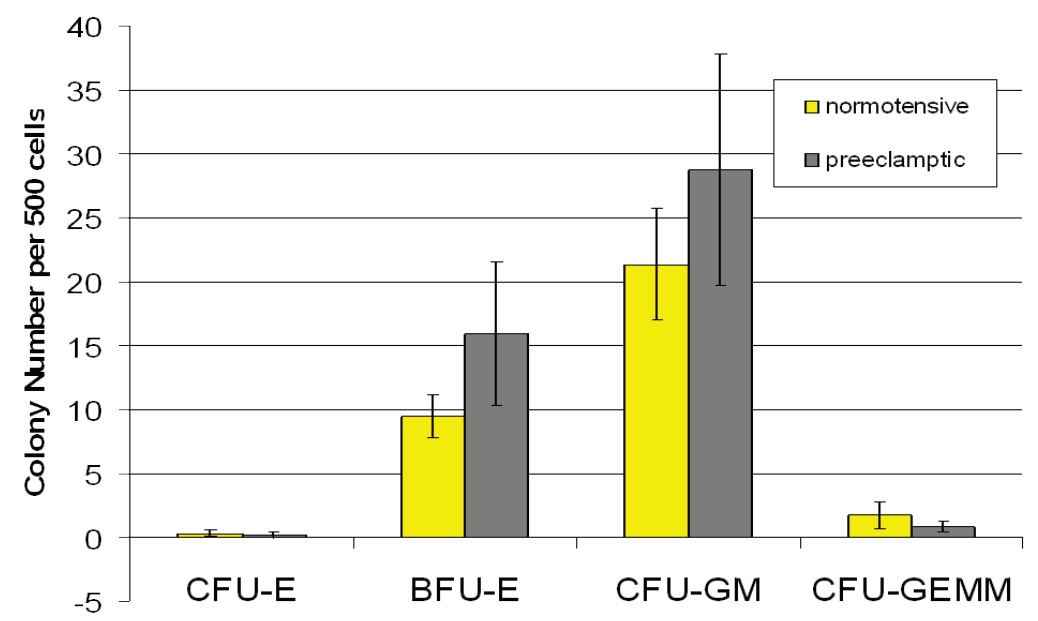

Figure 3. In vitro differentiation of CD34 ${ }^{+}$umbilical cord blood cells. Cell from the umbilical cord blood of children born to normotensive women represented by yellow bars and from preeclamptic women in grey.

\section{Discussion}

The fairly recent identification of the placenta as a site of definitive hematopoiesis raises many intriguing questions, including what are the effects of placental disease on the hematopoietic stem cells that arise there and whether this leads to any effects on the child. To begin to address these questions, we sought to understand whether there were differences in cytokine signals for cell growth and differentiation and whether hematopoietic stem cells isolated from the umbilical cord of children born to normotensive and preeclamptic women had any differences in differentiation potential in vitro.

One of the most well-defined mechanisms to alter cell differentiation is through cytokine signaling. In the case of erythroid cells, erythropoietin (EPO) is critically important. Therefore, we began our investigation by measuring EPO. Unlike other studies, we did not detect a statistically significant difference in EPO, although we did identify a trend toward increased EPO in cord blood of children born to preeclamptic women (Figure 1). ${ }^{17}$ Our results may not have reached significance because of the smaller sample size in our study compared to others. Our result suggests that it is unlikely that increased EPO alone is driving progenitor cells into erythroid cells. Given the role of osteopontin in regulating stem cell expansion and its elevation in preeclamptics women with extensive endothelial damage, we also measured OPN in the plasma of our umbilical cord blood samples. Interestingly, while OPN was not different in the maternal plasma of 
normotensive and preeclamptics by others, we found an increase in the plasma of cord blood of preeclamptics without regard to the severity of the preeclampsia. Therefore, this increase in OPN in cord blood plasma may be a reflection of the suppression of the stem cells rather than of endothelial damage in the child.

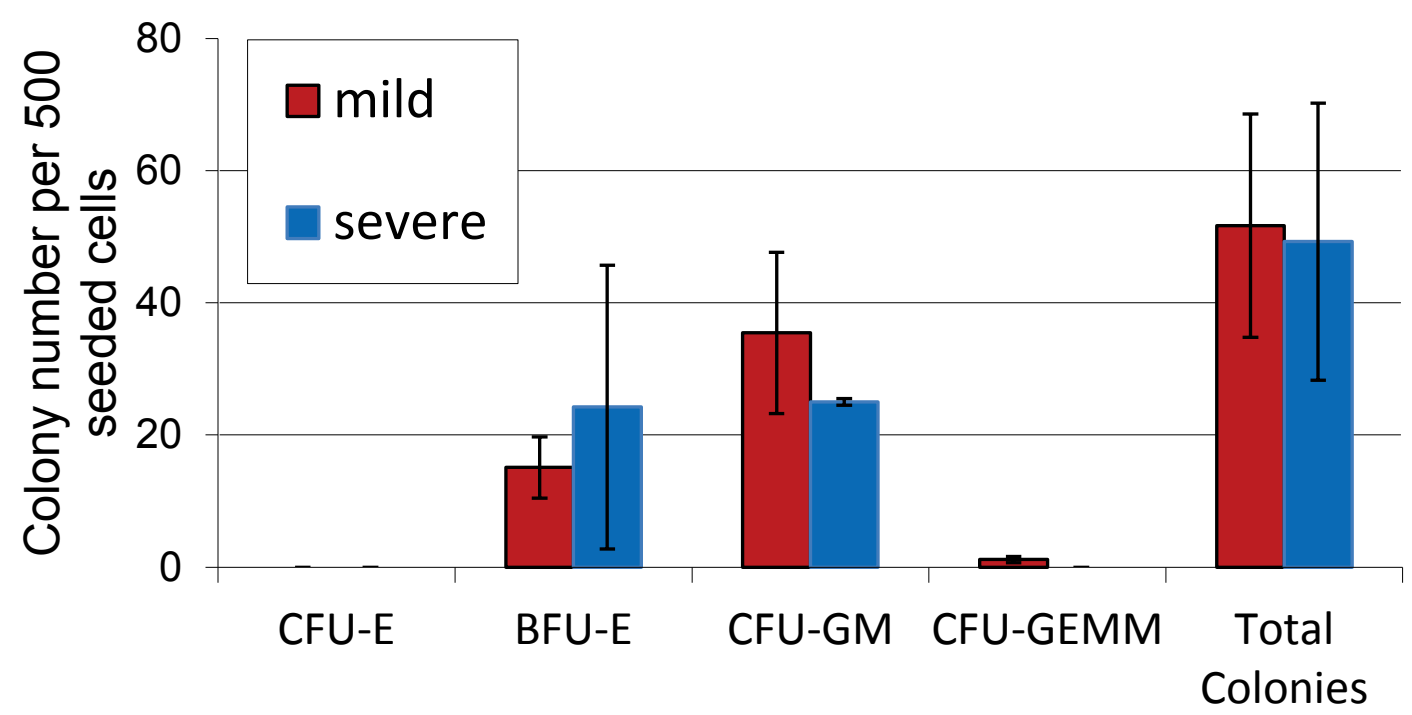

Figure 4. Comparison of in vitro differentiation of $\mathrm{CD} 34^{+}$cells from the umbilical cord blood of mild (dark red bars) and severe preeclamptics (blue bars).
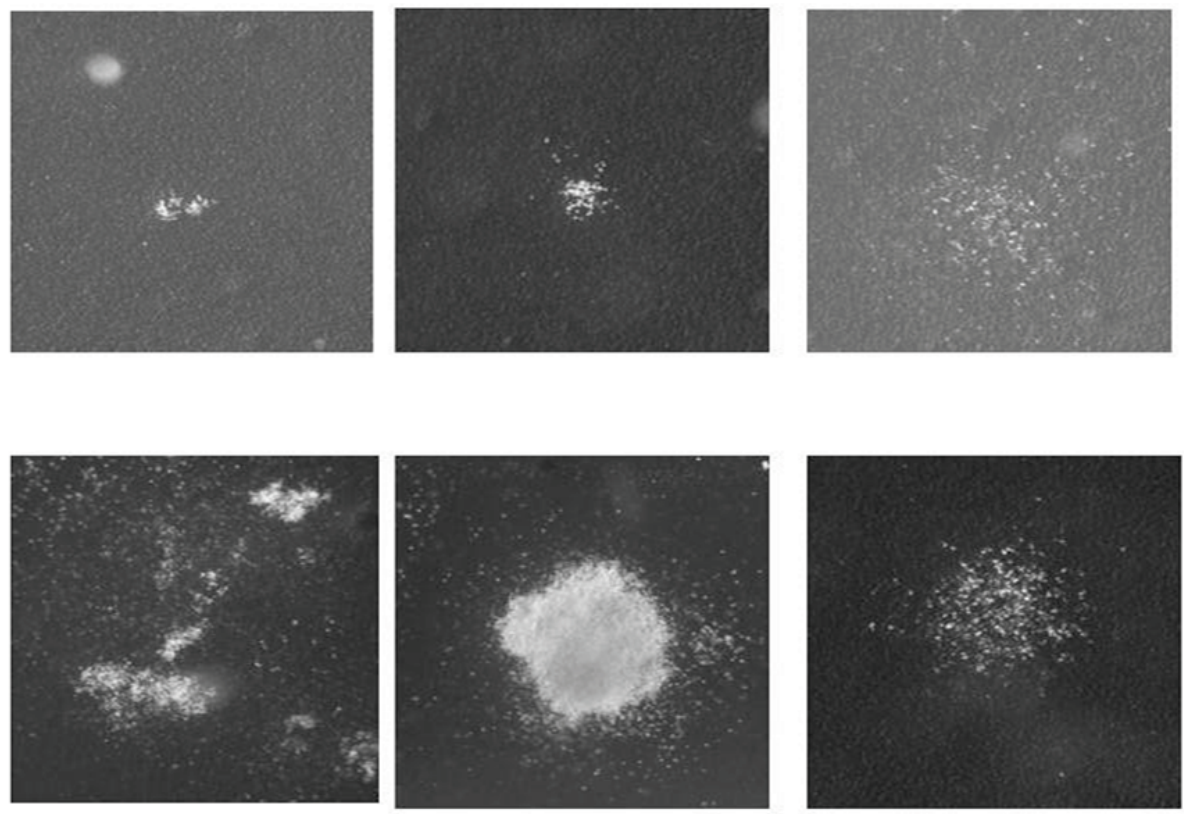

Figure 5. Colonies from preeclamptic samples appeared smaller in the colony assay. 
Table 3. Sample Characteristics

\begin{tabular}{|l|l|l|l|}
\hline Characteristic & Control & Preeclamptic & $P$ value \\
\hline $\begin{array}{l}\text { Average cord blood } \\
\text { volume collected }\end{array}$ & $99.6 \mathrm{ml}$ & $75.8 \mathrm{ml}$ & $0.15^{\mathrm{a}}$ \\
\hline $\begin{array}{l}\text { Average number of } \\
\text { CD34+ cells isolated }\end{array}$ & $4.7 \times 10^{5}$ & $5.5 \times 10^{5}$ & $0.75^{\mathrm{a}}$ \\
\hline
\end{tabular}

${ }^{\mathrm{a}} 2$-tailed $t$ test

Although there tended to be more erythroid precursors from the severe preeclamptic samples compared to the mild preeclamptic samples, the difference was not statistically significant. To clarify if the CD34+ cells isolated from the cord blood of preeclamptic and normotensive women would form the same colonies in vitro under conditions in identical growth media for cells, we began by analyzing umbilical cord blood to determine if there is a difference; however, this sample would contain hematopoietic stem cells generated by all sites of definitive hematopoiesis. As others have described differences in the cord blood cells of preeclamptics, we wanted to begin our investigation with these cells. $^{7,14,18}$ Given that with this mixed population we began to see differences in colonies, it would be interesting to isolate hematopoietic stem cells from placental tissue and to determine if this pool of cells specifically has an aberrant differentiation and growth potential in diseased placenta, such as in preeclampsia. Additionally, it would be informative to perform the colony assay under hypoxic conditions to determine if low oxygen conditions affect the differentiation potential of the CD34+ cells.

While not statistically significant, the trend toward an increased propensity to differentiate into erythroid precursors in cases of severe preeclampsia is interesting. In preeclampsia, the placenta is in a hypoxic state due to incomplete remodeling of the spiral arteries. We hypothesize that cells are primed to differentiate into erythroid cells to compensate for the hypoxia. Future studies will further explore this hypothesis.

Acknowledgements: This work was supported by the Department of Obstetrics \& Gynecology at the University of lowa Hospitals \& Clinics.

\section{References}

1. DiFederico E, Genbacev O, Fisher SJ. Preeclampsia is associated with widespread apoptosis of placental cytotrophoblasts within the uterine wall. Am J Pathol. 1999 Jul;155(1):293-301. PubMed PMID: 10393861; PubMed Central PMCID: PMC1866652. http://dx.doi.org/10.1016/S00029440(10)65123-1

2. Kadyrov M, Kingdom JC, Huppertz B. Divergent trophoblast invasion and apoptosis in placental bed spiral arteries from pregnancies complicated by maternal anemia and early-onset preeclampsia/intrauterine growth restriction. Am J Obstet Gynecol. 2006 Feb;194(2):557-63. PubMed PMID: 16458661.

http://dx.doi.org/10.1016/j.ajog.2005.07. 035 
3. Reister F, Frank HG, Heyl W, Kosanke G, Huppertz B, Schröder W, Kaufmann $P$, Rath W. The distribution of macrophages in spiral arteries of the placental bed in pre-eclampsia differs from that in healthy patients. Placenta. 1999 Mar-Apr;20(2-3):229-33. PubMed PMID: 10195746. http://dx.doi.org/10.1053/plac.1998.0373

4. Formigli L, Papucci L, Tani A, Schiavone N, Tempestini A, Orlandini GE, Capaccioli S, Orlandini SZ. Aponecrosis: morphological and biochemical exploration of a syncretic process of cell death sharing apoptosis and necrosis. J Cell Physiol. 2000 Jan;182(1):41-9. PubMed PMID: 10567915.

http://dx.doi.org/10.1002/(SICI)10974652(200001)182:1<41::AIDJCP5 $>3.0 . C O ; 2-7$

5. Goswami D, Tannetta DS, Magee LA, Fuchisawa A, Redman CW, Sargent IL, von Dadelszen P. Excess syncytiotrophoblast microparticle shedding is a feature of early-onset preeclampsia, but not normotensive intrauterine growth restriction. Placenta. 2006 Jan;27(1):56-61. Epub 2005 Jan 25. PubMed PMID: 16310038. http://dx.doi.org/10.1016/j.placenta.2004 .11 .007

6. Knight $M$, Duley $L$, Henderson-Smart DJ, King JF. Antiplatelet agents for preventing and treating pre-eclampsia. Cochrane Database Syst Rev. 2000;(2):CD000492. Update in: Cochrane Database Syst Rev. 2007;(2):CD000492. PubMed PMID: 10796208.

DOI: 10.1002/14651858.CD000492

7. Surbek DV, Danzer E, Steinmann C, Tichelli A, Wodnar-Filipowicz A, Hahn S, Holzgreve W. Effect of preeclampsia on umbilical cord blood hematopoietic progenitor-stem cells. Am J Obstet Gynecol. $2001 \quad$ Sep;185(3):725-9. PubMed $\quad$ PMID: 11568804. http://dx.doi.org/10.1067/mob.2001.117 343
8. Stallmach $T$, Karolyi $L$, Lichtlen $P$, Maurer M, Hebisch G, Joller H, Marti $\mathrm{HH}$, Gassmann M. Fetuses from preeclamptic mothers show reduced hepatic erythropoiesis. Pediatr Res. 1998 Mar;43(3):349-54. PubMed PMID: 9505273.

http://dx.doi.org/10.1203/00006450199803000-00007

9. Benian A, Uzun H, Aydin S, Albayrak M, Uludağ S, Madazli R. Placental stem cell markers in pre-eclampsia. Int $\mathrm{J}$ Gynaecol Obstet. 2008 Mar;100(3):22833. Epub 2007 Nov 28. PubMed PMID: 18048043.

http://dx.doi.org/10.1016/j.ijgo.2007.09.0 23

10. Gabinskaya T, Salafia CM, Gulle VE, Holzman IR, Weintraub AS. Gestational age-dependent extravillous cytotrophoblast osteopontin immunolocalization differentiates between normal and preeclamptic pregnancies. Am J Reprod Immunol. 1998 Nov;40(5):339-46. PubMed PMID: 9870077.

http://dx.doi.org/10.1111/j.1600-

0897.1998.tb00063.x

11. Alvarez-Silva $M$, Belo-Diabangouaya $P$, Salaün J, Dieterlen-Lièvre $F$. Mouse placenta is a major hematopoietic organ. Development. 2003 Nov;130(22):5437-44. Epub 2003 Sep 24. PubMed PMID: 14507780. http://dx.doi.org/10.1242/dev.00755

12. Mikkola HK, Gekas C, Orkin SH, Dieterlen-Lievre F. Placenta as a site for hematopoietic stem cell development. Exp Hematol. 2005 Sep;33(9):1048-54. PubMed PMID: 16140153. http://dx.doi.org/10.1016/j.exphem.2005. 06.011

13. Gekas C, Dieterlen-Lièvre F, Orkin SH, Mikkola HK. The placenta is a niche for hematopoietic stem cells. Dev Cell. 2005 Mar;8(3):365-75. PubMed PMID: 15737932. http://dx.doi.org/10.1016/j.devcel.2004.1 2.016 
14. Darmochwal-Kolarz D, LeszczynskaGorzelak B, Rolinski J, Oleszczuk J. Pre-eclampsia affects the immunophenotype of neonates. Immunol Lett. 2001 Jun 1;77(2):67-71. PubMed PMID: 11377699. http://dx.doi.org/10.1016/S01652478(01)00205-X

15. Stenczer B, Rigó J Jr, Prohászka Z, Derzsy Z, Lázár L, Makó V, Cervenak L, Balogh K, Mézes M, Karádi I, Molvarec A. Plasma osteopontin concentrations in preeclampsia - is there an association with endothelial injury? Clin Chem Lab Med. 2010 Feb;48(2):181-7. doi: 10.1515/CCLM.2010.042. PubMed Stier S, Ko Y, Forkert R, Lutz C, Neuhaus T, Grünewald E, Cheng T, Dombkowski

16. D, Calvi LM, Rittling SR, Scadden DT. Osteopontin is a hematopoietic stem cell niche component that negatively regulates stem cell pool size. J Exp Med. 2005 Jun 6;201(11):1781-91. Epub 2005 May 31. PubMed PMID: 15928197; PubMed Central PMCID: PMC2213260.PMID: 19943814. http://dx.doi.org/10.1084/jem.20041992

17. Gupta G, Gupta I, Suri V, Dhawan V, Ganguly NK. Estimation of cord blood erythropoietin in pre-eclampsia and eclampsia. Int J Gynaecol Obstet. 2000 Oct;71(1):1-5. PubMed PMID: 11044534 http://dx.doi.org/10.1016/S0020-

7292(00)00241-1

18. Wahid FS, Nasaruddin MZ, Idris MR, Tusimin M, Tumian NR, Mahdy ZA. Effects of preeclampsia on the yield of hematopoietic stem cells obtained from umbilical cord blood at delivery. J Obstet Gynaecol Res. 2012 Mar;38(3):490-7. doi: 10.1111/j.1447-0756.2011.01740.x. Epub 2012 Feb 16. PubMed PMID: 22381102. 